\title{
Polyadenylate-Binding Protein 1
}

National Cancer Institute

\section{Source}

National Cancer Institute. Polyadenylate-Binding Protein 1. NCI Thesaurus. Code C143074.

Polyadenylate-binding protein 1 ( $636 \mathrm{aa}, \sim 71 \mathrm{kDa}$ ) is encoded by the human PABPC1 gene. This protein is involved in binding to the poly(A) tail of mRNA. 